\title{
TJPS-47135-Original Article
}

Phytochemical screening and establishment of antidiabetic potentiality of aqueous leaf extract of endangered plant Decalepis nervosa in alloxan induced diabetic rats

\section{Short title: Decalepis nervosa aqueous leaves extract is evident of antidiabetic potential}

\author{
Kuntal Das, Saifulla Khan M, James Sounder, Usha Mohan, Venkatesh Prasad s \\ DEPARTMENT OF PHARMACOGNOSY AND PHYTOCHEMISTRY, KRUPANIDHI COLLEGE OF \\ PHARMACY, CARMELARAM POST, BANGALORE, INDIA
}

\begin{abstract}
Objective: To evaluate the presence of phytochemicals in AEDN plant species (Aqueous leaf extract of Decalepis nervosa) and antidiabetic activity in normal and alloxan induced diabetic rats.

Materials and Methods: Either sex rats were grouped into 5 classes. Alloxan monohydrate was used as induced diabetic whereas glibenclamide was used as standard drug. Medicinal endangered plant DN aqueous extract was used with two different doses. Diabetes was induced with Alloxan monohydrate at $150 \mathrm{mg} / \mathrm{kg} \mathrm{B}$.w. The AEDN was standardized with Pharmacognostical and phytochemical screening and chemical test confirmed the presence of phytoconstituents like glycoside, alkaloid, phenols, and flavonoids. Acute toxicity was performed for dose selection in antidiabetic study.

Results: Glibenclamide at $5 \mathrm{mg} / \mathrm{kg}$ b.w. and AEDN (200 mg and $400 \mathrm{mg}$ ) extract were given to all diabetic induced rats. The reduction of the blood glucose level may have correlation with the presence of plant secondary metabolites (phenolic compounds) which was identified by TLC and confirmed by HPLC studies. The decreased level of serum total cholesterol, triglyceride and liver enzymes activity resulted dose dependency of AEDN extract. OGTT was performed by administration of $200 \mathrm{mg}$ and $400 \mathrm{mg}$ of aqueous extract of DN and $5 \mathrm{mg}$ of glibenclamide to different groups respectively which significantly lower after oral glucose load during blood sample collection. Animal body weight and dose of AEDN extract showed significant effect on blood ghucose level $(* * \mathrm{P}<0.01)$. Conclusion: The first report on the phytochemicals and therapeutic activity of AEDN leaf was established with potential antidiabetic activity by increased insulin secretion via enhanced peripheral glucose utilization mechanism. Key words: Alloxan, biochemical estimation, correlation, Decalepis neryosa, Phytochemicals

Abbreviations: AEDN: Aqueous extract Decalepis nervosa; EDTA: Ethylenediamine tetraacetic acid; OECD: The Organisation for Economic Co-operation and Development; OGTT: Oral glucose tolerance test; AST: Aspartate aminotransferase; ALT: Alanine aminotransferase; ALP: Alkaline Phosphatase;

INTRODUCTION

Among the serious metabolic disorder, Diabetes mellitus (DM) is a most critical disorder throughout the World. India is listed in top three countries in the world. It is life threatening cause and responsible for many complications (such as, retinopathy, heuropathy and angiopathy) affecting various organs in the body, especially eyes first followed by dysfunction, and failure of various functional organs. Ample numbers of medicines are available in the pharma world market, but the related complications are increasing day by day. Hence traditional natural healing is an alternate method for the treatment of the same. Herbal plants are known for natural medicines. Literature survey revealed a vast number of plants are used for their hypoglycaemic activities without very less side effects or no side effects ${ }^{1}$. Hence searching of new plant originated phytoconstituents are the main focus which acts as novel antidiabetic plant without side effects.

Of late, Decalepis nervosa (Wight \& Arn.) Venter (DN) is one of the endangered plant species of Decalepis genus and Apocynaceae family. The other species are namely D. hamiltonii, D. arayalpathra, D. salicifolia and $D$. khasiana. DN is a medicinal plant, distributed throughout Western Ghats regions, the Nilgiris (Blue Mountains in Tamil), occupy the western corner of Tamil Nadu, borders Karnataka and Kerala states. The plant is a woody climbing shrub, stem is purplish, pubescent and the leaves content milky latex. Simple leaves are oppositely arranged. Leaves are elliptical shaped and acute ${ }^{2}$. There are many literatures available on the other species for their phytochemicals as well as medicinal activities but no such research evidences are available on DN leaves ${ }^{3}$. It is worthwhile to quantitative determine the phytoconstituents like flavonoids and total phenolics present in the leaf which is important for the correlation with the present study. Therefore the present challenge has undertaken phytochemical screening in relation to antidiabetic potential of aqueous leaf extract of DN and this is the first report on this plant for any therapeutic application with possible mechanism of action.
\end{abstract}




\section{MATERIALS AND METHODS}

\section{Plant material and preparation of extract}

Leaves of DN were collected from the forest area of Coimbatore, Tamil Nadu, (Western Ghat Region) and authenticated by the Botanist Prof. P.E Rajashekaran, Principal Scientist, Department of Biotechnology, IIHR, Hessaraghatta, Bangalore (Figure-1). A voucher herbarium specimen number DN-317/KCP/2018 was preserved in the Pharmacognosy Department of Krupanidhi College of Pharmacy, Bangalore. The collected leaves were dried under shade and coarsely powdered by mixer grinder and stored in an airtight container at room temperature. About $500 \mathrm{~g}$ of the fresh air-dried, powered leaf drug of DN was extracted with distilled water by reflux method for 6 hours. Then filtered and concentrated the extract using rotary flash evaporator ay $45^{\circ} \mathrm{C}$. The percentage yield was reported. The extract was preserved in a refrigerator at $4^{0} \mathrm{C}$ in a glass bottle until further use.

\section{Phytochemical analysis}

A preliminary qualitative test was carried out for the leaf extract by various chemical tests as per reported by Trease and Evans (2002) ${ }^{4}$. Further TLC of the extract was carried out with standard phenolic compound (Gallic acid) and flavonoid (Epicatechin, Catechin and rutin).

\section{Estimation of total flavonoids}

Total flavonoid content was determined by comparing with standard rutin $(25,50,150,300$ and $600 \mu \mathrm{g} / \mathrm{ml})$ with added aluminium trichloride. $125 \mu \mathrm{L}$ of extract solution was added with $75 \mu \mathrm{L}$ of $5 \% \mathrm{NaNO}_{2}$ solution. The mixture was kept for stand for 10 min and thereafter $10 \%$ aluminium trichloride $(150 \mu \mathrm{L})$ was added and incubated for 5 mins. After that $750 \mu \mathrm{L}$ of $1 \mathrm{M} \mathrm{NaOH}$ was added to that and the final volume of the solution was adjusted with distilled water up to $2500 \mu \mathrm{L}$. A pink color was appeared after $15 \mathrm{~min}$ of incubation the mixed solution. Finally the absorbance was measured at $510 \mathrm{~nm}$ for the solution (pink colour). From the standard curve of rutin, the total flavonoids is measured and expressed as $\mathrm{mg}$ E catechin/g dry matter ${ }^{5}$.

\section{Estimation of total phenolics}

Total phenolic content in AEDN was determined by spectrophotometry using the Folin-Ciocalteu assay. 1 $\mathrm{ml}$ of extract was diluted in $9 \mathrm{ml}$ of distilled water and $1 \mathrm{ml}$ of Folin-Ciocalteu phenol reagent was added to the solution. After 10 minutes, $7 \%$ Sodium carbonate solution $(10 \mathrm{ml})$ was added and the final volume was made up to $25 \mathrm{ml}$. Standard solutions of Gallic acid were prepared at various concentrations (20, 40, 60, 80 and $100 \mu \mathrm{g} / \mathrm{ml})$. The solution mixture was kept for 2 hours at room temperature and then absorbance was recorded at $550 \mathrm{~nm}$ using a UV spectrophotometer (for both test and standard solutions). Blank sample was prepared for reading corrections. The phenolics content is determined and expressed as $\mathrm{mg}$ of Gallic acid equivalent of extract ${ }^{6}$.

\section{Acute oral toxicity studies}

As per the OECD guideline (draft guideline No. 423 adopted), the acute oral toxicity studies of AEDN were carried out on July 2018 received from CPCSEA, meeting held in Krupanidhi College of Pharmacy, Bangalore ${ }^{7}$. Minimum number of animals $(n=3)$ were kept fasting over night with only drinking water and in the next day administration of the aqueous DN leaf extract was carried out from $50 \mathrm{mg} / \mathrm{kg} \mathrm{B.w.} \mathrm{up} \mathrm{to} \mathrm{the} \mathrm{dose} 5000 \mathrm{mg} / \mathrm{kg} \mathrm{B}$.w. in the tested animals. AEDN dose was administered and animals were kept overnight under observation followed by observing up to 7 days for any changes in general behavior and other physical activities. After 24h, there were no animal's death observe which indicates the safety action of the aqueous extract.

\section{Experimental animals and their groupings}

Adult either sex Albino Wistar rats (150-200g) of were procured from Adithi Biosys, Tumkur and maintained in the animal house of Krupanidhi College of Pharmacy. The animals were well acclimatized under controlled temperature $\left(22 \pm 5^{\circ} \mathrm{C}\right)$ and humidity $(55 \pm 5 \%) .12 \mathrm{~h}$ light and dark cycles were maintained and as a basal diet, standard pellets obtained from Sri Manjunatha Rice mill, Ganagular Panchayathi, Hosakote Taluk, were used during the experimental period and all the animals were given normal food and drinking water ad libitum. Whole experiments were conducted as per the ethical norms approved by CPCSEA and ethical clearance was granted by institutional ethical committee on $14^{\text {th }}$ February, 2018 at Krupanidhi College of Pharmacy, Bangalore (Ethical committee IAEC reg. no: KCP/PCOL/15/2018). Drugs like Alloxan monohydrate (drug used for induce diabetic) (Spectrochem Pvt. Ltd. Mumbai), standard drug, Glibenclamide (Aventis Pharma Ltd, Verna, Goa), Glucose (Emkay Labs, India), Accu-chekÆ Active Glucometer (Roche Diagnostic Corporation Germany) to check glucose level and blood gluco-strips (Roche Diagnostic Pvt. Ltd. Mumbai) were used.

The study was conducted on forty Wistar albino rats with five groups $(n=8)$ were randomly allocated to each of the five groups $(8 \times 5=40)$. The groups were treated as follows:

Group I: Normal rats, no treatment only water and food.

Group II: Diabetic rats treated with alloxan $(150 \mathrm{mg} / \mathrm{kg}$ b.w.) by i.p injection.

Group III: Induced diabetic rats with orally given DN aqueous leaf extract ( $200 \mathrm{mg} / \mathrm{kg} \mathrm{b.w}$ ) once daily for 28 days (Induced diabetic+ DN $200 \mathrm{mg} / \mathrm{kg}$ ).

Group IV: Induced diabetic rats with orally given DN aqueous leaf extract ( $400 \mathrm{mg} / \mathrm{kg} \mathrm{b.w}$ ) once daily for 28 days (Induced diabetic+ DN $400 \mathrm{mg} / \mathrm{kg}$ ). 
Group V: Induced diabetic rats with standard glibenclamide at $5 \mathrm{mg} / \mathrm{kg} \mathrm{b.w}$. once daily for 28 days (oral).

At the end of the experiment, the rats were sacrificed by cervical decapitation and blood was collected with EDTA as anticoagulant and plasma was separated by centrifuged blood at $3000 \mathrm{rpm}$ for 20 minutes. The serum was separated from blood without EDTA and centrifuged at $6000 \mathrm{rpm}$ for 10 minutes.

\section{Induction of diabetes}

The animals were allowed to acclimatize for one-two weeks and then a freshly prepared solution of alloxan monohydrate (dissolved in $0.9 \%$ normal saline solution) at a dose of $150 \mathrm{mg} / \mathrm{kg}$ body weight injected by $i . p$ to the experimented rats. Hyperglycemic rats were made after treating with alloxan by tail vein blood glucose level with the help of glucometer. The concentration of glucose level (>250 mg/dl) was considered as a hyperglycemic condition in the experiment ${ }^{8}$.

\section{Oral glucose tolerance test (OGTT)}

Fasted rats were separated into four groups, with each eight animals. Group- I: treated as control, Group-II: treated with standard drug, Group-III and IV: Different extracts. All rats from all the groups were orally treated with $2 \mathrm{~g} / \mathrm{kg}$ of glucose after 30 minutes of extract administration. Then blood samples were collected (the rat tail vein) prior to glucose administration $\left(0^{\text {th }}\right.$ minute) and at 30,60 and 90 minutes after glucose administered ${ }^{9}$. Gluco-meter was used to measure blood glucose levels in animals.

\section{Body weight measurement}

Body weight was measured four times during the course of the study period (i.e., on, before alloxan induced (initial values), days $0,7,21$ and 28 of the treatment period, using a digital weighing balance and recorded as initial body weight (IBW) and final body weight (FBW) respectively ${ }^{10}$.

\section{Estimation of Blood Glucose level ${ }^{11}$}

Blood samples were collected from the rat's tail at weekly intervals up to end of study (i.e., 4 weeks). Blood glucose was estimated by one touch electronic glucometer using blood glucose-strips. On $28^{\text {th }}$ day, blood was collected from the retro-orbital plexus (used carbon dioxide gas for anesthesia) from overnight fasted rats and blood sugar (fasted) was estimated. Separated serum was analyzed for serum cholesterol, serum triglycerides by enzymatic DHBS colorimetric method, serum HDL, serum LDL, serum creatinine, serum urea as well as the activities of alkaline phosphatase (ALP), aspartate and alanine transaminases (AST and ALT) were determined using Randox Assay kits. Statistical analysis

Results were analyzed by compared values for control to the different treated groups and expressed as mean \pm SEm. One-way analysis of variance followed by Dunnet's t-test for multiple comparisons was applied. Values with P < 0.05 were considered significant. Further blood glucose was tested based on the dose and body weight of animals using 2 x 2 full factorial design with replicate (Table-1). Eight experiments were constructed, varying the dose and body weight using software JMP version 11. Using this design the magnitude of the effect of each parameter on the resulted response of blood glucose were calculated. Each parameters were tested at 2 levels i.e. dose (low, $200 \mathrm{mg}$

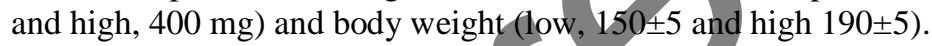

\section{RESULTS AND DISCUSSION}

\section{Primary phytochemical evaluation}

Extraction of DN plant was carried out and percentage yield was calculated as $5.28 \%(26.4 \mathrm{~g} \mathrm{w} / \mathrm{w})$.

Chemical tests of an aqueous extract of new plant like DN carried out and revealed the presence of phytoconstituents like alkaloids, flavonoids, glycoside and phenols, which play an important role in controlling diabetes. Further TLC of extract in Chloroform, methanol and water as mobile phase (6:3:1) was shown the presence of phenolics (Gallic acid) and flavonoid (rutin) in the extract (figure-2) which was further reconfirmed with the HPLC study (figure-3). HPLC data showed retention time $\left(\mathrm{R}_{\mathrm{t}}\right)$ of standard rutin and standard gallic acid at 7.58 mins and 3.10 mins respectively at $203 \mathrm{~nm}$ with the mobile phase methanol: water (60:40) (Figure-3a and 3b). Same conditions was followed for the AEDN extract and showed the presence of these two compounds (Rutin and Gallic acid) in the extract with the Rt of 7.58 mins and 3.10 mins respectively (Figure-3c). Further estimated the amount by comparing with standards and found that higher amounts of Gallic acid present $(2.32 \mu \mathrm{g})$ in leaf than rutin (0.054 $\mu \mathrm{g})$. Hence two compounds such as Gallic acid and Rutin were identified in the DN extract which was the first report in this investigation.

Phytochemical evaluation with respect to chemical tests is required to identify preliminary

phytoconstituents present in the herbal extracts. Plant phytoconstituents are essential for therapeutic efficacy. Hence, chemical test gives the path for the possible mechanism for the particular disease treatment as well as discovery of novel drugs from the isolated constituent. Mechanisms of action of phytoconstituents involve either regulating glycemic metabolism or decreasing cholesterol levels or increasing secretion of insulin or by improving microcirculation. The present investigation was carried out for qualitative identification of phytoconstituents present in the aqueous extract of DN, an endangered plant species. Aqueous extract was selected because most of the 
important phytoconstituents related to antidiabetic activity, are soluble in aqueous solvent. Furthermore aqueous solvent is cost effective and easily available than other solvents, as well in future for preparation of herbal formulations aqueous extract of plant sample is widely acceptable.

\section{Estimation of total flavonoids and total phenolics}

The catechin solution of concentration $(25-600 \mathrm{ppm})$ conformed to Beer's Law at $510 \mathrm{~nm}$ with a regression co-efficient $\left(\mathrm{R}^{2}\right)=0.997$. The plot has a slope $(\mathrm{m})$ of 0.000 and an intercept of 0.031 . The equation of standard curve is $\mathrm{y}=0.000 \mathrm{x}+0.031$ (Figure- 4, Table-2) and the amount was found as $2.52 \mathrm{mg}$.

The total phenolics in AEDN were estimated by Folin Ciocalteu's method using Gallic acid as standard. The Gallic acid solution of concentration (20-100 ppm) conformed to Beer's Law at $550 \mathrm{~nm}$ with a regression coefficient $\left(\mathrm{R}^{2}\right)=0.997$. The plot has a slope $(\mathrm{m})$ of 0.012 and an intercept of 0.025 . The equation of standard curve is $\mathrm{y}=0.012 \mathrm{x}+0.025$ (Figure-5, Table-2) and the amount was found as $5.81 \mathrm{mg}$.

Table-2 indicated the amount of flavonoids and phenolics are present in quite high amount. It $y$ at that higher concentration of phenolics as well as flavonoids highly soluble in polar solvent like water ${ }^{12}$. They mainly acts as antioxidant activity and also plays vital role in antidiabetic activity due to presence of hydroxyl groups, some double bonds (C-2-C-3) and C-4 ketonic functional groups in their structures ${ }^{13,14}$. Therefore it wa essential to determine the total flavonoids and phenolics contents in AEDN leaf.

\section{Acute oral toxicity study of DN leaf extract}

The nontoxic nature of the AEDN is revealed with acute oral toxicity. There were no lethality or toxic reactions found till dose of $5000 \mathrm{mg} / \mathrm{kg}$ as per the OECD guideline until the end of the study period. All the animals were alive, healthy, and active during the observation period that indicates the selected plant extract is safe for the present experiment and two suitable doses were selected i.e. $200 \mathrm{mg} / \mathrm{kg}$ b.w and $400 \mathrm{mg} / \mathrm{kg} \mathrm{B.w.}$

Acute toxicity study of AEDN leaf was carried out to determine the lethal dose $\left(\mathrm{LD}_{50}\right)$. The study confirmed $\mathrm{LD}_{50}$ when two selected doses result in mortality higher than 0\% and lower than 100\%. Many literatures revealed this study before experimentation for safety dose determination and as per that the present study was performed for the new endangered plant species and resulted selected doses were safe for the further investigation ${ }^{15}$, 16 .

\section{Oral glucose tolerance test (OGTT)}

The effects of AEDN on OGTT in normal rats were estimated. After 30 mins of glucose administration the rapid increased in blood glucose resulted in the fasting animals and then decreased subsequently during the time intervals. Standard Glibenclamide administered group $(5 \mathrm{mg} / \mathrm{kg}$ ) reduced hyperglycemia (glucose induced) significantly at $30 \mathrm{~min}, 60 \mathrm{~min}$ and $90 \mathrm{~min}(103.32 \pm 0.10,102.11 \pm 0.01$ and $84.60 \pm 0.11$ respectively) as compared to normal control at the same time intervals respectively. Maximum glucose tolerance in AEDN was observed as 92.22 \pm 0.03 and the minimum was obseryed as $87.22 \pm 0.11$ in 90 minutes as compared with Group-I (Table-3) $(* * \mathrm{P}<0.01)$.

OGTT was carried out to measure the ability to use a type of sugar by the body. Result revealed dose dependent manner reduction of glucose when treated with DN extract orally due to identified flavonoids and phenolics in AEDN leaf ${ }^{17}$.

\section{Body weight measurement}

Body weight of all rats was determined four times i.e., on, before alloxan induction, days 0, 7, 21 and 28 and the result was depicted in table-3 where group II initially increased followed by significant reduction of body weight in $21^{\text {st }}$ day $(156.19 \mathrm{~g})$ and $28^{\text {th }}$ day $(150.11 \mathrm{~g})$ than an initial day $(174.10 \mathrm{~g})$. Gr-IV and V also showed a significant reduction $\left(\mathrm{p}<0.01^{* *}\right)$ in body weight compared to normal in $28^{\text {th }}$ day $($ Table-4) by dose dependent manner. In the present study, standard drug (alloxan) caused marked reduction in body weight whereas AEDN increased body weight significantly. This is may be due excessive fat utilized from fatty tissue for energy production in the body. The result is similar to that of earlier reports ${ }^{18}$ were dose dependent gaining in body weight with the treated plant extract. Alloxan is reported to cause significant reduction in insulin release by smashing the beta cells (of islets of Langerhans) and induces hyperglycemia in animals ${ }^{19}$ that resulted decrease in body weight which may be due to catabolism of fats and proteins or by dehydration.

Estimation of Blood Glucose level and serum analysis

The blood glucose was estimated at the intervals of 1, 7, 14, 21, 28 days respectively. Glibenclamide and DN aqueous extract treated group $(200,400 \mathrm{mg} / \mathrm{kg})$, showed significant reduction $(\mathrm{P}<0.05)$ from the $7^{\text {th }}$ day to $28^{\text {th }}$ day. Alloxan induced DN aqueous extract @ $400 \mathrm{mg}$ showed significant reduction of blood glucose level $\left(\mathrm{p}<0.05^{*}\right)$ (Figure-6). 
Animals induced with alloxan $150 \mathrm{mg} / \mathrm{kg}$ b.w (i.p), elevated blood glucose in $1^{\text {st }}$ day and after 28 days it reduced little but more than normal groups. Alloxan was used to induce diabetes without production of insulin. The result showed dose-dependent decrease in fasting blood glucose in diabetic rats treated with different doses of the DN extract. This dose-dependent effect compares well with glibenclamide especially at the dose of $400 \mathrm{mg} / \mathrm{kg}$ body weight the extract produced a more significant reduction of blood glucose level than $5 \mathrm{mg} / \mathrm{kg}$ glibenclamide on the 28th day, which may be due to improved control mechanisms of glycemic as well as insulin secretions from pancreatic cells of diabetic rats ${ }^{20}$. Furthermore, oxygen free radicals are involved in the diabetogenic action of alloxan and DN plant extract containing flavonoids, phenolics that are shown to be effective in diabetes due their antioxidants property ${ }^{21,22}$. Thereafter flavonoids are reported to suppress glucose level and also found to be a strong inhibitor of $\alpha$-glucosidase (mainly luteolin) ${ }^{23}$. DN leaves extracts also showed the presence of phenolics in higher content and that is the reason for decrease in bold glucose level. Identified compounds such as gallic acid which is phenolics compound, enhanced insulin secretion and thereafter release from the beta cells ${ }^{24}$ in this present study. In other hand, rutin which was identified in DN extract as flavonoids was also boosted in reduction of blood glucose in the present study. It acts by increasing the peripheral utilization of glucose with inhibits glucose transport from intestine, which directly effects on significant reduction of blood glucose in both normal and diabetic rats.

Glibenclamide (standard) is used in the present investigation because it caused voltage-dependent calcium channel depolarization of cell membrane and hence increased in intracellular calcium of beta cell that subsequently stimulates insulin secretion to treat diabetes ${ }^{25}$.

\section{Serum lipids analysis}

On $28^{\text {th }}$ day, Alloxan treated animals increased the serum glucose, cholesterol, serum triglycerides, LDL, creatinine and urea and decrease the HDL level, but glibenclamide $(5 \mathrm{mg} / \mathrm{kg}$ ) and DN aqueous extract in two different doses reversed the above alloxan induce changes. Both the extracts showed significant elevation ( $P<0.05)$ in serum HDL level compared to diabetic control rats after 28 days of treatment in a dose dependent manner (Table-5). In the present study, HDL-cholesterol was slightly lesser value with significant $(\mathrm{P}<0.05)$ increase in the level of LDL-cholesterol in diabetic control group as compared to other treatment groups. Thereafter, mean values of HDLcholesterol were significantly $(\mathrm{P}<0.05)$ increased, while mean values of $\mathrm{LDL}-$ cholesterol were significant $(\mathrm{P}<0.05)$ decreased in both glibenclamide and in DN extract treated groups showed their potential to have hypolipidemic action which was similar to that of earlier many literatures ${ }^{26}$ showed the same results. Diabetic is resulted from carbohydrate, protein and lipid metabolism. Diabetes mellitus results in hyperlipidemia due to abnormalities of lipid metabolism, which in turn leads to atherosclerosis, myocardial infaraction, etc ${ }^{27}$. Increased HDL level plays a significant role in the human body and known as 'beneficial Cholesterol' because its increased level associated with a decreased risk of myocardial infarction by removal of cholesterol from other tissues to the liver. It fosters the removal of cholesterol from peripheral tissue to the liver for catabolism and excretion and competes with LDL receptor sites on arterial smooth muscle cells that partially inhibit LDL uptake and degradation. Furthermore HDL plays a role in lipid metabolism, complement regulation, immune response and excess cholesterol brings back to the liver that helped to convert into bile acids and finally excreted into the small intestine ${ }^{26}$. An aqueous extract of DN leaves plays significant role in decreased level of serum cholesterol, serum glucose, serum triglycerides, LDL, creatinine and urea and increased the level of HDL this indicates DN leaves are a good source of antidiabetic drug by reduction of risk of developing the heart disease. This may be due to the presence of polyphenolic compounds, especially flavonoids in the leaves which are incorporated into lipoprotein within the liver or intestine and transported within the lipoprotein particle. Mainly flavonoids consumption is inversely associated with mortality from coronary heart diseases and hence flavonoids and phenolics are may be located for protection of LDL from oxidation. The same result reyealed by the earlier scientific evidence ${ }^{28}$.

\section{Serum enzyme level}

Serum enzymes such as Alkaline phosphatase (ALP), Aspartate and alanine transaminases (AST and ALT) activities were determined. The activity of enzymes is increased much higher (alloxan induced rats) than normal, which gave significant (***P<0.001) results in 28 days. Furthermore diabetic induced standard drug showed significant decrease in enzyme activity than alloxan induced animals. With DN aqueous extract the same are also decreased significantly and the values are nearly to glibenclamide standard drug $(* * \mathrm{P}<0.01)$ and the decreased levels are dose dependent manner in 28 days (Figure-7).

In the current study, there was a significant elevation of the enzyme activities such as AST, ALT

and ALP in diabetic control group than the normal control group and thereafter diabetic induced standard drug decreased the values, but were more than normal control that might be due to cell membrane damage of hepatocytes or may be due to increased cell membrane permeability or. The similar research was also established by earlier literature ${ }^{29}$. AST and ALT are well-known enzymes used as biomarkers to determine possible toxicity in the liver. Increased levels of AST, ALT and ALP in diabetic rats indicate excessive accumulation of glutamate and alanine in the serum of diabetic animals from protein stores. The elevated activities of ALT, AST, ALP (serum aminotransferases) in liver indicate cardiovascular diseases as well as diabetes among people. The activities of ALT, 
AST and ALP in serum is increased due to the leakage of these enzymes (in the liver cytosol) ${ }^{30}$ and as a result diabetes may induce hepatic dysfunction. When DN aqueous extract administered orally to diabetic induced animals, it resulted significant reduction of serum enzymes such as AST, ALT and ALP than alloxan induced diabetes. This indicates the extract has liver protection activity due to the presence of flavonoids as the result is correlated with the earlier study ${ }^{31}$. Results obtained from the present study are clearly in agreement with previous reports by related to hepatoprotective activity of menthi, guduchi, and gymnema herbal extracts, respectively in restoring back the elevated levels of ALT, AST and ALP in diabetes ${ }^{32,33}$.

\section{Effect of different doses of AEDN and body weight of animals on blood glucose level}

The Full factorial design was evaluated at significance level of $\mathrm{P}<0.05$. The variance analysis of overall experimentation showed $\mathrm{P}$ value 0.0017 (Table-6).

Analysis of response to blood glucose showed the actual by predicting plot with an RMSE $=1.028$ (Figure-8).

The leverage plot showed (Figure 9,10 and 11) the significant effect of dose and body weight of animals and its confounding effects with blood glucose level. The data showed in Table-7. The response surface graph as shown in figure-12 explored the relationship between body weight and dose on blood glucose.

Finally, 2 x 2 full factorial statistical design studies confirmed that the significant effect of body weight and dose on blood glucose reduction. This result confirmed that present endangered DN species have essential phytoconstituents especially polyphenolic compounds (rutin and Gallic acid) that resulted potential antidiabetic activity.

\section{CONCLUSION}

The present study concludes that various plant constituents viz. flavonoids, phenolics, glycosides and alkaloids are present in endangered AEDN leaf. TLC and HPLC study confirmed rutin and gallic acid in an extract which may trigger the insulin secretion and demonstrated significant lowering of blood glucose level, serum sugar level, biochemical parameters and statistical improvement in body weight of animals in dose dependent manners by enhanced peripheral glucose utilization by direct stimulation of glucose uptake and reduce blood glucose level. The acute oral toxicity study revealed the safety use of all these chemical compounds that are present in DN extract. Hence, it is clear that these compounds could give hypoglycemic effect in diabetic people. Furthermore first time 2 X 2 factorial design studies were carried out and resulted, significant correlation of dose of DN extract and body weight of animals in lowering of blood glucose level. Therefore, it is ascertained that AEDN leaf has antidiabetic activity. Further study is under process for isolation of active constituents for new discovery of drugs from DN plant.

\section{REFERENCES}

1. Upendra Rao M, Sreenivasulu M, Chengaiah B, Jaganmohan Reddy K, Madhusudhana Chetty C. Herbal medicines for diabetes mellitus: a review. Int J Pharm Tech Res. 2010; 2: 1883-1892.

2. Solomon Raju AJ, Venkata Ramana K. Lonta GM. Traditional preparation of a health drink Nannari Sharbat from the root extract of Decalepis hamiltonii Wight \& Arn. Ind J Nat Prod Resources. 2011; 2(1): 121-124. 3. Sharma S, Shahzad A. An Overview on Decalepis: A Genus of Woody Medicinal Climbers. J Plant Sci Res. 2014; 1(1): 104.

4. Trease G, Evans SM. Pharmacognosy. 15th ed. London: Bailer Tindal. 2002, p.23-67.

5. Struchkov P, Beleborodov V, Kolkhir V, Voskoboynikova I, Savvateev A. Comparison of spectrophotometric methods of total flavonoid assay based on complex formation with aluminium chloride as applied to multicomponent herbal drug angionom. J Pharm Negative Results. 2018; 9: 1-7.

6. Sembiring EN, Elya B, Sauriasari R. Phytochemical Screening, Total Flavonoid and Total Phenolic Content, and Antioxidant Activity of Different Parts of Caesalpinia bonduc (L.) Roxb. Pharmacog J. 2018; 10(1):123-127.

7. Unuofin JO, Otunola GA, Afolavan AJ. Evaluation of acute and subacute toxicity of whole-plant aqueous extract of Vernonia mespilifolia Less. in Wistar rats. J Integr Med. 2018;16(5):335-341.

8. Kotadiya Chintu R, Patel Urvesh D, Patel Harshad B, Modi Chirag M, Fefar Dhaval T. Evaluation of effects of Opuntia elatior Mill. fruit juice and quercetin on biochemical parameters and histopathological changes in diabetic rats. Ind. J Trad Know. 2018; 17(3): 576-583.

9. Hepcy KD, Dinakar A, Senthil KN. Antidiabetic activity of ethanolic extracts of Alangium salvifolium and Pavonia zeylanica in streptozotocin induced diabetic rats. Int J Pharm Pharmaceuti Sci. 2012; 4(1): 337-339.

10. Olatunde A, Joel EB, Tijjani H, Obidola SM, Luka CD. Anti-diabetic activity of aqueous extract of Curcuma longa (Linn) rhizome in normal and alloxan-induced diabetic rats. Researcher. 2014; 6(7): 58-65.

11. Singh A, Srivastav R, Pandey AK. Effect of the seeds of Terminalia chebula on blood serum, lipid profile and urine parameters in STZ induced Diabetic rats. J Pharmacog Phytochem. 2018; 7(2): 1-5. 
12. Dehpeur MA, Ibrahimzadeh N, Fazel NS, Mohammad NS. Antioxidant activity of the methanol extract of Ferula assafoetida and its essential oil composition. Grasas Y Aceites. 2009; 60: 405-412.

13. Sarian MN, Ahmed QU, Mat So'ad SZ, Alhassan AM, Murugesu S, Perumal V, et al. Antioxidant and Antidiabetic Effects of Flavonoids: A Structure-Activity Relationship Based Study. Bio Med Res Int. 2017. Article ID 8386065, 14 pages, doi.org/10.1155/2017/8386065.

14. Karima O, Righi S, Belhocin A, Mekness A, Meddah B, Tirtouil A. Phytochemical Study and Antioxidant Activity of Some Anti-Diabetic Plants in the Wilaya of Mascara. J Antimicrob Agents. 2018; 4(1): 1-5. doi:10.4172/2472-1212.1000165.

15. Ecobichon DJ. New York: CRC press. The basis of toxicology testing, 1997, pp. 43-86.

16. Saeed F, Ahmad M. Anti-diabetic and acute toxicity studies of Annona squamosa L. ethanolic leaves extract. Int J Phytomedicine. 2017; 9(4): 642-647.

17. Sornalakshmi V, Tresina Soris P, Paulpriya K, Packia Lincy M, Mohan VR. Oral Glucose Tolerance Test (OGTT) in Normal Control and Glucose Induced Hyperglycemic Rats with Hedyotis leschenaultiana DC. Int J Toxicol Pharmacol Res. 2016; 8(1): 59-62.

18. Tomar RS, Sisodia SS. Antidiabetic activity of Annona squamosa Linn. in alloxan-induced diabetic rats. Int J Green Pharm. 2014; 237-241.

19. Balamurugan K, Nishanthini A, Mohan VR. Antidiabetic and antihyperlipidaemic activity of ethanol extract of Melastoma malabathricum Linn. leaf in alloxan induced diabetic rats. Asian Pac J Trop Biomed. 2014; 4(Suppl 1): S442-S448.

20. Jansen J, Lai YC. Regulation of muscle glycogen synthase phosphorylation and kinetic properties by insulin, exercise, adrenaline and role in insulin resistance (review). Arch Physiol Biochem. 2009 ; 115 (1): $13-21$. 21. Jafri MA, Aslam M, Kalim J, Surender S. Effect of Punica granatum Linn. (flowers) on blood glucose level in normal and alloxan-induced diabetic rats. J. Ethnopharmacol. 2000; 70: 309-314.

22. Syed MA, Vrushabendra SB, Gopkumar P, Dhanapal R, Chandrashekara. Anti-diabetic activity of Terminalia catappa Linn. leaf extracts in alloxan-induced diabetic rats. Int J Pharm Technol. 2005; 4: 36-39.

23. Kim JS, Kwon CS, Son KH. Inhibition of alpha-glucosidase and amylase by luteolin, a flavonoid. Biosci Biotechnol Biochem. 2000; 64 (11): 2458-2461.

24. Sameermahmood Z, Raji L, Saravanan T, Vaidya A, Mohan V, Balasubramanyam M. Gallic acid protects RINm5F $\beta$-cells from glucolipotoxicity by its antiapoptotic and insulin-secretagogue actions. Phytother Res. 2010; 24: S83-S94.

25. Serrano-Martín X, Payares G, Mendoza-León A. Glibenclamide, a blockerof K+ATP channels, shows antileishmanial activity in experimental murine cutaneous leishmaniasis. Antimicrob Agents Chemother. 2006; 50 (12): 4214-4216.

26. Ortega FJ, Gimeno-Bayon J, Espinosa-Parrilla JF, Carrasco JL, Batlle M, Pugliese M, et al. ATP-dependent potassium channel blockade strengthens microglial neuroprotection after hypoxia-ischemia in rats. Exp Neurol. 2012; 235(1): 282-296.

27. Yadav AV, Undale VR, Bhosle AV. Antidiabetic activity of Plumeria rubra L. in normal and alloxan induced diabetic mice. Int J Basic Clinic Pharmacol. 2016; 5(3): 884-889.

28. Khan A, Safdar M, Ali khan MM. Effect of various doses of cinnamon on lipid profile in diabetic individuals. Pak J nutri. 2003; 2: 313-319.

29. Nwufo KC, Ene AC, Emejulu AA, Obasi UK, Ene CU. Antidiabetic properties of ethanolic root extract of Mucuna pruriens on alloxan induced diabetic rats. Int J Res Pharm and Biosciences. 2017; 4(5): 17-29.

30. Rahman MF. Effects of vepacide (Azadirachta indica) on aspartate and alanine aminotransferase profiles in a subchronic study with rats. Human Experi Toxicol. 2001; 20(5): 243-249.

31. Stanely P, Prince M, Menon VP. Hypoglycaemic and other related actions of Tinospora cordifolia roots in alloxan induced diabetic rats. J Ethnopharmacol. 2000; 70(1): 9-15.

32. Renuka C, Ramesh N, Saravanan K. Evaluation of the antidiabetic effect of Trigonella foenum-graecum seed powder on alloxan induced diabetic albino rats. Int J pharm Tech Res. 2009; 1(4): 1580-1584.

33. Aziza AME, Magda ME, Moshira M ES, Hannen HMO, Doaa SI. Effect of Gymnema sylvestre R. Br.leaves extract on certain physiological parameters of diabetic rats. J King Saud Univer Sci. 2013; $25(3)$ : $135-141$.

Table-1: 2 x 2 Full factorial model

\begin{tabular}{|l|l|l|l|}
\hline Runs & Pattern & Dose in mg & Body weight in gms \\
\hline 1 & +2 & 400 & High \\
\hline 2 & -1 & 200 & low \\
\hline 3 & +2 & 400 & High \\
\hline
\end{tabular}




\begin{tabular}{|l|l|l|l|}
\hline 4 & +1 & 400 & low \\
\hline 5 & -2 & 200 & High \\
\hline 6 & -2 & 200 & High \\
\hline 7 & -1 & 200 & low \\
\hline 8 & +1 & 400 & low \\
\hline
\end{tabular}

Table-2: Total flavonoids and total Phenolics content in aqueous extract of DN

\begin{tabular}{|l|l|l|l|}
\hline Extract & Part used & Total flavonoids (mg/g) & Total Phenolics (mg/g) \\
\hline Aqueous extract of DN & Leaves & $0.52 \pm 0.18$ & $0.58 \pm 0.02$ \\
\hline
\end{tabular}

Table-3: Effects of aqueous extract of DN on glucose tolerance test

\begin{tabular}{|l|l|l|l|l|l|l|}
\hline Groups & $\begin{array}{l}\text { Dose } \\
(\mathrm{mg})\end{array}$ & $\begin{array}{l}\text { Dose after 30mins } \\
(2 \mathrm{~g} / \mathrm{kg})\end{array}$ & $0^{\text {th }} \mathrm{min}$ & $30^{\text {th }} \mathrm{min}$ & $60^{\text {th }}$ min & $90^{\text {th }} \min$ \\
\hline Normal & Vehicle & Glucose & $87.02 \pm 0.23$ & $197.12 \pm 0.14$ & $189.36 \pm 0.11$ & $186.02 \pm 0.02$ \\
\hline $\begin{array}{l}\text { Diabetic } \\
\text { induced + } \\
\begin{array}{l}\text { Standard drug } \\
\text { glibenclamide }\end{array}\end{array}$ & 5 & Glucose & $83.07 \pm 0.11$ & $103.32 \pm 0.10^{* *}$ & $102.11 \pm 0.011^{* *}$ & $84.60 \pm 0.11^{* *}$ \\
\hline $\begin{array}{l}\text { Diabetic } \\
\text { induced + DN } \\
\text { aqueous leaf } \\
\text { extract }\end{array}$ & 200 & Glucose & $82.86 \pm 0.20$ & $106.11 \pm 0.23^{* *}$ & $99.40 \pm 0.20^{* *}$ & $92.22 \pm 0.03^{* *}$ \\
\hline $\begin{array}{l}\text { Diabetic } \\
\text { induced + DN } \\
\text { aqueous leaf } \\
\text { extract }\end{array}$ & 400 & Glucose & $83.09 \pm 0.03$ & $102.22 \pm 0.20^{* *}$ & $97.02 \pm 0.11^{* *}$ & $87.22 \pm 0.11$ \\
\hline
\end{tabular}

Values are expressed as mean $\pm \mathrm{SE}(\mathrm{n}=8)$. $* \mathrm{P}<0.05 * * \mathrm{P}<0.01 * * * \mathrm{P}<0.001$ when compared with normal group (ANOVA followed by Dunnet's test)

Table-4: The effect of 4-week treatment with aqueous extract of DN on body weight (g) after alloxan (150 $\mathrm{mg} / \mathrm{kg}$ i.p.) induced diabetes in rats.

\begin{tabular}{|l|l|l|l|l|l|l|}
\hline Group & $\begin{array}{l}\text { Dose } \\
(\mathbf{m g})\end{array}$ & $\mathbf{0}^{\text {th }}$ day $(\mathbf{g})$ & $\mathbf{7}^{\text {th }}$ day $(\mathbf{g})$ & $\mathbf{1 4}^{\text {th }}$ day & $\mathbf{2 1}^{\text {st }}$ day & $\mathbf{2 8}^{\text {th }}$ day \\
\hline $\begin{array}{l}\text { Normal control } \\
\text { (Gr-I) }\end{array}$ & vehicle & $163.21 \pm 0.01$ & $163.28 \pm 0.22$ & $165.18 \pm 0.10$ & $168.33 \pm 0.01^{*}$ & $169.21 \pm 0.01^{* *}$ \\
\hline $\begin{array}{l}\text { Diabetic control } \\
\text { (Gr-II) }\end{array}$ & 150 & $174.10 \pm 0.11$ & $172.20 \pm 0.04$ & $164.57 \pm 0.22$ & $156.19 \pm 0.12^{*}$ & $150.11 \pm 0.23^{* *}$ \\
\hline $\begin{array}{l}\text { Diabetic } \\
\text { induced + } \\
\text { Standard drug } \\
\text { glibenclamide } \\
\text { (Gr-III) }\end{array}$ & 5 & $168.27 \pm 0.22$ & $165.10 \pm 0.20$ & $165.27 \pm 0.11$ & $166.04 \pm 0.24^{*}$ & $167.11 \pm 0.03^{* *}$ \\
\hline $\begin{array}{l}\text { Diabetic } \\
\text { induced + DN } \\
\text { aqueous leaf } \\
\text { extract } \\
\text { (Gr-IV) }\end{array}$ & 200 & $184.22 \pm 0.21$ & $174.01 \pm 0.24$ & $166.30 \pm 0.04$ & $158.22 \pm 0.23^{*}$ & $151.06 \pm 0.12^{* *}$ \\
\hline $\begin{array}{l}\text { Diabetic } \\
\text { induced + DN } \\
\text { aqueous leaf } \\
\text { extract } \\
\text { (Gr-V) }\end{array}$ & 400 & $182.24 \pm 0.31$ & $176.20 \pm 0.20$ & $169.11 \pm 0.01$ & $164.34 \pm 0.21^{*}$ & $156.48 \pm 0.22^{* *}$ \\
\hline
\end{tabular}

Values are expressed as mean $\pm \mathrm{SEm}(\mathrm{n}=8) . * \mathrm{P}<0.05 * * \mathrm{P}<0.01 * * * \mathrm{P}<0.001$ when compared with normal group (ANOVA followed by Dunnet's test) 
Table-5: Effect of various groups of DN aqueous extract on serum profile in alloxan $(150 \mathrm{mg} / \mathrm{kg}$, i.p.) induced diabetic rats after 28 days of treatment (Fasting condition)

\begin{tabular}{|c|c|c|c|c|c|}
\hline Parameters & Group & & & & \\
\hline & $\begin{array}{l}\text { Normal } \\
\text { control } \\
\text { (Gr-I) }\end{array}$ & $\begin{array}{l}\text { Diabetic control } \\
\text { (Gr-II) }\end{array}$ & $\begin{array}{l}\text { Diabetic induced } \\
\text { + glibenclamide } \\
\text { (Gr-III) }\end{array}$ & $\begin{array}{l}\text { Diabetic } \\
\text { induced }+ \text { DN } \\
\text { aqueous leaf } \\
\text { extract } \\
(200 \mathrm{mg}) \\
(\mathrm{Gr}-\mathrm{IV})\end{array}$ & $\begin{array}{l}\text { Diabetic induced + } \\
\text { DN aqueous leaf } \\
\text { extract } \\
(400 \mathrm{mg}) \\
(\mathrm{Gr}-\mathrm{V})\end{array}$ \\
\hline $\begin{array}{l}\text { serum glucose } \\
(\mathrm{mg} / \mathrm{dl})\end{array}$ & $82.83 \pm 0.13$ & $282.40 \pm 0.23^{* *}$ & $145.50 \pm 0.12^{*}$ & $151.33 \pm 0.12^{*}$ & $14766+$ \\
\hline $\begin{array}{l}\text { total cholesterol } \\
(\mathrm{mg} / \mathrm{dl})\end{array}$ & $74.66 \pm 0.20$ & $170.33 \pm 0.10^{* *}$ & $98.20 \pm 0.02^{*}$ & $106.50 \pm 0.10^{*}$ & \\
\hline $\begin{array}{l}\text { Serum } \\
\text { triglycerides } \\
(\mathrm{mg} / \mathrm{dl})\end{array}$ & $56.83 \pm 0.11$ & $154.00 \pm 0.04^{* *}$ & $93.66 \pm 0.31^{*}$ & $98.00 \pm 0.02^{*}$ & \\
\hline $\begin{array}{l}\text { Serum HDL } \\
(\mathrm{mg} / \mathrm{dl})\end{array}$ & $48.83 \pm 0.03$ & $36.16 \pm 0.14^{* *}$ & $46.86 \pm 0.10^{*}$ & & \\
\hline $\begin{array}{l}\text { serum LDL } \\
(\mathrm{mg} / \mathrm{dl})\end{array}$ & $49.05 \pm 0.24$ & $132.74 \pm 0.20^{* *}$ & $51.06 \pm 0.16^{*}$ & & $0.41^{*}$ \\
\hline $\begin{array}{l}\text { serum creatinine } \\
(\mathrm{mg} / \mathrm{dl})\end{array}$ & $45.56 \pm 0.21$ & $138.16 \pm 0.10^{* *}$ & $61.80 \pm 0.21^{*}$ & & \\
\hline $\begin{array}{l}\text { Serum urea } \\
(\mathrm{mg} / \mathrm{dl})\end{array}$ & $48.23 \pm 0.22$ & $141.14 \pm 0.11^{* *}$ & $57.12 \pm 0.32^{*}$ & $\bar{\sigma}$ & $62.03 \pm 0.04^{*}$ \\
\hline
\end{tabular}

Values are expressed as mean $\pm \mathrm{SE}(\mathrm{n}=8) .{ }^{*} \mathrm{P}<0.05 * * \mathrm{P}<0.01 * * * \mathrm{P}<0.001$ (ANOVA followed by Dunnet's test). Diabetic control was compared with normal control and extract treated groups were compared with the diabetic control.

Table-6: Analysis of variance

\begin{tabular}{|l|l|l|l|l|}
\hline Source & DF & $\begin{array}{l}\text { Sum of } \\
\text { Squares }\end{array}$ & Mean Square & F Ratio \\
\hline Model & 3 & 86.752150 & 28.9174 & 42.2121 \\
\hline Error & 4 & 2.740200 & 0.6851 & Prob $>$ F \\
\hline C. Total & 7 & 89.492350 & & $0.0017^{*}$ \\
\hline
\end{tabular}

Table-7: Effect of dose and body weight its confounding effects with blood glucose level

\begin{tabular}{|l|l|l|l|l|}
\hline Term & Estimate & Std Error & t Ratio & Prob>|t| \\
\hline Intercept & 63.065 & 0.363555 & 173.47 & $<.0001^{*}$ \\
\hline Dose (200,400) & -1.8575 & 0.363555 & -5.11 & $0.0069^{*}$ \\
\hline Body weight[low] & 2.185 & 0.363555 & 6.01 & $0.0039^{*}$ \\
\hline Dose* Body weight[low] & -1.1675 & 0.363555 & -3.21 & $0.0325^{*}$ \\
\hline
\end{tabular}

Table-1: 2 × 2 Full factorial model

\begin{tabular}{|l|l|l|l|}
\hline Runs & Pattern & Dose in mg & Body weight in gms \\
\hline 1 & +2 & 400 & High \\
\hline 2 & -1 & 200 & low \\
\hline 3 & +2 & 400 & High \\
\hline 4 & +1 & 400 & low \\
\hline 5 & -2 & 200 & High \\
\hline 6 & -2 & 200 & High \\
\hline 7 & -1 & 200 & low \\
\hline 8 & +1 & 400 & low \\
\hline
\end{tabular}

Table-2: Total flavonoids and total Phenolics content in aqueous extract of DN 


\begin{tabular}{|l|l|l|l|}
\hline Extract & Part used & Total flavonoids (mg/g) & Total Phenolics (mg/g) \\
\hline Aqueous extract of DN & Leaves & $0.52 \pm 0.18$ & $0.58 \pm 0.02$ \\
\hline
\end{tabular}

Table-3: Effects of aqueous extract of DN on glucose tolerance test

\begin{tabular}{|c|c|c|c|c|c|c|}
\hline Groups & $\begin{array}{l}\text { Dose } \\
(\mathrm{mg})\end{array}$ & $\begin{array}{l}\text { Dose after 30mins } \\
(2 \mathrm{~g} / \mathrm{kg})\end{array}$ & $0^{\text {th }} \min$ & $30^{\text {th }} \min$ & $60^{\text {th }} \min$ & $90^{\text {th }} \min$ \\
\hline Normal & Vehicle & Glucose & $87.02 \pm 0.23$ & $197.12 \pm 0.14$ & $189.36 \pm 0.11$ & $186.02 \pm 0.02$ \\
\hline $\begin{array}{l}\text { Diabetic } \\
\text { induced }+ \\
\text { Standard drug } \\
\text { glibenclamide }\end{array}$ & 5 & Glucose & $83.07 \pm 0.11$ & $103.32 \pm 0.10^{* *}$ & $102.11 \pm 0.01^{* *}$ & $84.60 \pm 0.11^{* *}$ \\
\hline $\begin{array}{l}\text { Diabetic } \\
\text { induced }+ \text { DN } \\
\text { aqueous leaf } \\
\text { extract }\end{array}$ & 200 & Glucose & $82.86 \pm 0.20$ & $106.11 \pm 0.23^{* *}$ & $99.40 \pm 0.20^{* *}$ & \\
\hline $\begin{array}{l}\text { Diabetic } \\
\text { induced + DN } \\
\text { aqueous leaf } \\
\text { extract }\end{array}$ & 400 & Glucose & $83.09 \pm 0.03$ & $102.22 \pm 0.20^{* *}$ & 97.02 & \\
\hline
\end{tabular}

Values are expressed as mean $\pm \mathrm{SE}(\mathrm{n}=8)$. $* \mathrm{P}<0.05 * * \mathrm{P}<0.01 * * * \mathrm{P}<0.001$ when compared with normal group

(ANOVA followed by Dunnet's test)

Table-4: The effect of 4-week treatment with aqueous extract of DN on body weight (g) after alloxan (150 $\mathrm{mg} / \mathrm{kg}$ i.p.) induced diabetes in rats.

\begin{tabular}{|l|l|l|l|l|l|l|}
\hline Group & $\begin{array}{l}\text { Dose } \\
(\mathbf{m g})\end{array}$ & $\mathbf{0}^{\text {th }}$ day $(\mathbf{g})$ & $\mathbf{7}^{\text {th }}$ day $(\mathbf{g})$ & $\mathbf{1 4}^{\text {th }}$ day & $\mathbf{2 1}^{\text {st }}$ day & $\mathbf{2 8}^{\text {th }}$ day \\
\hline $\begin{array}{l}\text { Normal control } \\
\text { (Gr-I) }\end{array}$ & vehicle & $163.21 \pm 0.01$ & $163.28 \pm 0.22$ & $165.18 \pm 0.10$ & $168.33 \pm 0.01^{*}$ & $169.21 \pm 0.01^{* *}$ \\
\hline $\begin{array}{l}\text { Diabetic control } \\
\text { (Gr-II) }\end{array}$ & 150 & $174.10 \pm 0.11$ & $172.20 \pm 0.04$ & $164.57 \pm 0.22$ & $156.19 \pm 0.12^{*}$ & $150.11 \pm 0.23^{* *}$ \\
\hline $\begin{array}{l}\text { Diabetic } \\
\text { induced + } \\
\text { Standard drug } \\
\text { glibenclamide } \\
\text { (Gr-III) }\end{array}$ & 5 & $168.27 \pm 0.22$ & $165.10 \pm 0.20$ & $165.27 \pm 0.11$ & $166.04 \pm 0.24^{*}$ & $167.11 \pm 0.03^{* *}$ \\
\hline $\begin{array}{l}\text { Diabetic } \\
\text { induced + DN } \\
\text { aqueous leaf } \\
\text { extract } \\
\text { (Gr-IV) }\end{array}$ & 200 & $184.22 \pm 0.21$ & $174.01 \pm 0.24$ & $166.30 \pm 0.04$ & $158.22 \pm 0.23^{*}$ & $151.06 \pm 0.12^{* *}$ \\
\hline $\begin{array}{l}\text { Diabetic } \\
\text { induced + DN } \\
\text { aqueous leaf } \\
\text { extract } \\
\text { (Gr-V) }\end{array}$ & & & & & & \\
\hline
\end{tabular}

Values are expressed as mean $\pm \mathrm{SEm}(\mathrm{n}=8) . * \mathrm{P}<0.05 * * \mathrm{P}<0.01 * * * \mathrm{P}<0.001$ when compared with normal group (ANOVA followed by Dunnet's test)

Table-5: Effect of various groups of DN aqueous extract on serum profile in alloxan $(150 \mathrm{mg} / \mathrm{kg}$, i.p. $)$ induced diabetic rats after 28 days of treatment (Fasting condition)

\begin{tabular}{|c|c|c|c|c|c|}
\hline \multirow[t]{2}{*}{\begin{tabular}{|l|} 
Parameters \\
\end{tabular}} & \multicolumn{5}{|l|}{ Group } \\
\hline & $\begin{array}{l}\text { Normal } \\
\text { control } \\
(\text { Gr-I) }\end{array}$ & $\begin{array}{l}\text { Diabetic control } \\
\text { (Gr-II) }\end{array}$ & $\begin{array}{l}\text { Diabetic induced } \\
+ \text { glibenclamide } \\
\text { (Gr-III) }\end{array}$ & $\begin{array}{l}\text { Diabetic } \\
\text { induced + DN } \\
\text { aqueous leaf }\end{array}$ & $\begin{array}{l}\text { Diabetic induced + } \\
\text { DN aqueous leaf } \\
\text { extract }\end{array}$ \\
\hline
\end{tabular}




\begin{tabular}{|l|l|l|l|l|l|}
\hline & & & & $\begin{array}{l}\text { extract } \\
(200 \mathrm{mg}) \\
(\mathrm{Gr}-\mathrm{IV})\end{array}$ & $\begin{array}{l}(400 \mathrm{mg}) \\
(\mathrm{Gr}-\mathrm{V})\end{array}$ \\
\hline $\begin{array}{l}\text { serum glucose } \\
(\mathrm{mg} / \mathrm{dl})\end{array}$ & $82.83 \pm 0.13$ & $282.40 \pm 0.23^{* *}$ & $145.50 \pm 0.12^{*}$ & $151.33 \pm 0.12^{*}$ & $147.66 \pm 0.24^{*}$ \\
\hline $\begin{array}{l}\text { total cholesterol } \\
(\mathrm{mg} / \mathrm{dl})\end{array}$ & $74.66 \pm 0.20$ & $170.33 \pm 0.10^{* *}$ & $98.20 \pm 0.02^{*}$ & $106.50 \pm 0.10^{*}$ & $100.83 \pm 0.13^{*}$ \\
\hline $\begin{array}{l}\text { Serum } \\
\text { triglycerides } \\
(\mathrm{mg} / \mathrm{dl})\end{array}$ & $56.83 \pm 0.11$ & $154.00 \pm 0.04^{* *}$ & $93.66 \pm 0.31^{*}$ & $98.00 \pm 0.02^{*}$ & $95.10 \pm 0.11^{*}$ \\
\hline $\begin{array}{l}\text { Serum HDL } \\
(\mathrm{mg} / \mathrm{dl})\end{array}$ & $48.83 \pm 0.03$ & $36.16 \pm 0.14^{* *}$ & $46.86 \pm 0.10^{*}$ & $64.33 \pm 0.11^{*}$ & $76.50 \pm 0.40^{*}$ \\
\hline $\begin{array}{l}\text { serum LDL } \\
(\mathrm{mg} / \mathrm{dl})\end{array}$ & $49.05 \pm 0.24$ & $132.74 \pm 0.20^{* *}$ & $51.06 \pm 0.16^{*}$ & $54.78 \pm 0.32^{*}$ & $46.90 \pm 0.41^{*}$ \\
\hline $\begin{array}{l}\text { serum creatinine } \\
(\mathrm{mg} / \mathrm{dl})\end{array}$ & $45.56 \pm 0.21$ & $138.16 \pm 0.10^{* *}$ & $61.80 \pm 0.21^{*}$ & $65.60 \pm 0.34^{*}$ & $63.07 \pm 0.03^{*}$ \\
\hline $\begin{array}{l}\text { Serum urea } \\
\text { (mg/dl) }\end{array}$ & $48.23 \pm 0.22$ & $141.14 \pm 0.11^{* *}$ & $57.12 \pm 0.32^{*}$ & $64.12 \pm 0.14^{*}$ & $62.03 \pm 0.04^{*}$ \\
\hline
\end{tabular}

Values are expressed as mean $\pm \mathrm{SE}(\mathrm{n}=8)$. ${ }^{*} \mathrm{P}<0.05 * * \mathrm{P}<0.01 * * * \mathrm{P}<0.001$ (ANOVA followed by Dunnet's test). Diabetic control was compared with normal control and extract treated groups were compared with the diabetic control.

Table-6: Analysis of variance

\begin{tabular}{|l|l|l|l|l|}
\hline Source & DF & $\begin{array}{l}\text { Sum of } \\
\text { Squares }\end{array}$ & Mean Square & F Ratio \\
\hline Model & 3 & 86.752150 & 28.9174 & 42.2121 \\
\hline Error & 4 & 2.740200 & 0.6851 & Prob $>$ F \\
\hline C. Total & 7 & 89.492350 & & $0.0017^{*}$ \\
\hline
\end{tabular}

Table-7: Effect of dose and body weight its confounding effeets with blood glucose level

\begin{tabular}{|l|l|l|l|l|}
\hline Term & Estimate & Std Error & t Ratio & Prob $>|\mathbf{t}|$ \\
\hline Intercept & 63.065 & 0.363555 & 173.47 & $<.0001^{*}$ \\
\hline Dose (200,400) & -1.8575 & 0.363555 & -5.11 & $0.0069^{*}$ \\
\hline Body weight[low] & 2.185 & 0.363555 & 6.01 & $0.0039^{*}$ \\
\hline Dose*Body weight[low] & -1.1675 & 0.363555 & -3.21 & $0.0325^{*}$ \\
\hline
\end{tabular}

